\title{
Progress in understanding and treating age-related macular degeneration
}

Eye (2008) 22, 739-741; doi:10.1038/sj.eye.6703035

In this special edition of Eye, we review the progress made in the understanding and treatment of age-related macular degeneration (AMD). This seems an appropriate time to do so due to the tremendous advances made in the last 5 years; first in dissecting the basic aetiology of the disease and second in turning this knowledge into useful treatments for patients.

The earliest descriptions of AMD dated from 1884 and $1885{ }^{1,2}$ but until relatively recently knowledge of the basis of the disease and how to treat it were limited. When I began training in ophthalmology in 1991, treatment of AMD was mainly limited to the prescription of low visual aids. A few patients benefitted from thermal laser but most became severely visually impaired. Most clinicians thought that it was an environmental disease. Large-scale epidemiological studies evaluated the diets of septuagenarians at the age of 20 years but amazingly did not think it necessary to ask about family history. Sixteen years later, our paradigms have been radically altered by molecular genetic research.

We now know that AMD is a complex disease with a strong genetic component; indeed, out of an estimated 25 million sufferers worldwide, a genetic defect can be identified in approximately $75 \%$ of cases. ${ }^{3}$ In particular, mutations in complement genes that lead to dysregulation of the complement pathway are frequently at fault. ${ }^{4-11}$ This is a remarkable progress considering that 5 years ago no AMD genes were known. What is also surprising is that we know of several genes of large effect ie individual genes, which are each mutated in upto $50 \%$ of patients. Therefore, in the future large-scale population screening would be relatively easy to achieve as only a small

A Lotery

number of assays would be needed. Mutations in complement factor $\mathrm{H}(\mathrm{CFH})$ and HTRA serine peptidase 1 (HTRA1) contribute to over $70 \%$ of the population attributable risk of AMD. ${ }^{3}$ It is intriguing that a widespread defence mechanism such as complement activation should result in a localised disease in the eye. Work presented by Chau et $a l^{12}$ in this edition also suggests that AMD can be considered a systemic disease with raised plasma matrix metalloproteinase9 levels.

So, should we screen our patients for these genetic risk factors? The answer currently is 'no', as it will not alter treatment. Interim guidelines from the Royal College of Ophthalmologists are published with this edition, which give current guidance on management. ${ }^{13}$ So, what is the point of finding these genes? First, an understanding of the fundamental aetiology is vital in order to create the most effective treatments. We now know that genes that regulate complement activation or are involved in the complement cascade are frequently mutated in patients with AMD. This now provides new drug targets for this disease. It is feasible that in the future we will offer personalised medicine based on a patient's underlying genetic background

(pharmacogenetics); for example, we may screen for complement gene mutations and then offer treatment with oral complement inhibitors. Identification of the major genes, which when mutated lead to this disease, is the first step on this exciting path. Goverdhan $e t a l^{14}$ present work in this edition on how genotypephenotype correlations may develop to guide treatment in the future.

Environmental factors are also important in the development of this disease. Smoking is a major environmental risk factor ${ }^{15}$ but most patients are unaware of this. This message
Andrew Lotery Clinical Neurosciences Division, University of Southampton, Southampton, UK 
needs to be disseminated more widely - that smoking causes blindness. In addition, obesity ${ }^{16}$ and poor diet are also likely to contribute to the development of AMD. The Age-Related Eye Disease Study (AREDS) showed that a combination of vitamins and antioxidants can reduce the risk of progression of AMD by $25 \% .{ }^{17}$ The AREDS 2 study should answer the question of whether lutein, zeaxanthin or omega- 3 acids are also beneficial.

Several pioneering studies have also radically altered our treatment of choroidal neovascularisation (CNV) associated with AMD. First, the macular photocoagulation studies both helped in creating a classification of subtypes of $\mathrm{CNV}$ and in determining the role of thermal laser. ${ }^{18}$ Subsequently, the treatment of AMD with photodynamic therapy (TAP) and verteporfin in photodynamic therapy (VIP) studies ${ }^{19,20}$ showed the effectiveness of photodynamic laser treatment, and more recently it has become clear just how potent agents that can inhibit vascular endothelial growth factor (VEGF) are in the treatment of $\mathrm{CNV}^{21-24} \mathrm{~A}$ major challenge for ophthalmology and the National Health Service (NHS) in the United Kingdom is how to accommodate these agents both in terms of cost and infrastructure. In this edition, Cervantes-Castañeda et $a l^{25}$ highlight how further work in early detection of AMD is needed in order to maximise the benefits of these novel treatments, while Leys et $a l^{26}$ show the benefits of improving quality of life for AMD patients, if we are successful in introducing timely treatment.

Approximately one-third of patients see significant visual recovery when treated with ranibizumab and similar figures have been reported with bevacizumab. ${ }^{24,27,28}$ Are they of equal efficacy? To answer this question, a randomised controlled trial has been funded in the United Kingdom (the IVAN trial) and a second similar study will take place in the United States. The IVAN trial will provide guidance on reducing total number of treatments and increasing re-treatment intervals, and should improve our understanding of how the different drugs work. Collectively, these studies will thus help ophthalmologists decide on efficacy, rather than just on cost, which drug should be made available in the NHS. Many other countries are likely to be guided by this research as they try to make the best use of limited healthcare resources. In addition, genotypephenotype correlations will also be analysed and so personalised treatment may develop from this research. It will be interesting to see if underlying genotype predicts the $30 \%$ in whom vision improves with treatment.

In the near future, we can expect to learn more about why the recently discovered mutations in genes that disrupt complement pathways selectively result in the phenotype of AMD. Many new drugs that inhibit VEGF are in development and could lead to less arduous treatment regimens for patients with CNV. Alternatively, we may be using surgery particularly in those patients who have developed end-stage disciform scarring. An example of such pioneering work is described by Heussen et al. ${ }^{29}$

AMD is a disease of epidemic proportions but, as the studies in this special edition show, much progress is now being made in its treatment, which is great news for patients. Ophthalmologists and scientists who have contributed to these studies should be justly proud of the progress made.

\section{References}

1 Nettleship E. Central senile areolar choroidal dystrophy. Trans Am Ophthalmol Soc 1884; 6: 165-168.

2 Haab O. Erkrankungen der Macula Lutea. Zentralbl Augenheilkd 1885; 9: 384-391.

3 Lotery A, Trump D. Progress in defining the molecular biology of age-related macular degeneration. Hum Genet 2007; 122: 219-236.

4 Edwards AO, Ritter III R, Abel KJ, Manning A, Panhuysen C, Farrer LA. Complement factor H polymorphism and agerelated macular degeneration. Science 2005; 308: 421-424.

5 Haines JL, Hauser MA, Schmidt S, Scott WK, Olson LM, Gallins $\mathrm{P}$ et al. Complement factor $\mathrm{H}$ variant increases the risk of age-related macular degeneration. Science 2005; 308: 419-421.

6 Klein RJ, Zeiss C, Chew EY, Tsai JY, Sackler RS, Haynes C et al. Complement factor $\mathrm{H}$ polymorphism in age-related macular degeneration. Science 2005; 308: 385-389.

7 Hughes AE, Orr N, Esfandiary H, az-Torres M, Goodship T, Chakravarthy $\mathrm{U}$ et al. A common CFH haplotype, with deletion of CFHR1 and CFHR3, is associated with lower risk of age-related macular degeneration. Nat Genet 2006; 38: 1173-1177.

8 Maller J, George S, Purcell S, Fagerness J, Altshuler D, Daly MJ et al. Common variation in three genes, including a noncoding variant in $\mathrm{CFH}$, strongly influences risk of age-related macular degeneration. Nat Genet 2006; 38: 1055-1059.

9 Yates JR, Sepp T, Matharu BK, Khan JC, Thurlby DA, Shahid $\mathrm{H}$ et al. Complement $\mathrm{C} 3$ variant and the risk of age-related macular degeneration. $N$ Engl J Med 2007; 357: 553-561.

10 Gold B, Merriam JE, Zernant J, Hancox LS, Taiber AJ, Gehrs $\mathrm{K}$ et al. Variation in factor B (BF) and complement component $2(\mathrm{C} 2)$ genes is associated with age-related macular degeneration. Nat Genet 2006; 38: 458-462.

11 Hageman GS, Anderson DH, Johnson LV, Hancox LS, Taiber AJ, Hardisty LI et al. From the cover: a common haplotype in the complement regulatory gene factor $\mathrm{H}(\mathrm{HF} 1 / \mathrm{CFH})$ predisposes individuals to age-related macular degeneration. Proc Natl Acad Sci USA 2005; 102: 7227-7232.

12 Chau KY, Sivaprasad S, Patel N, Donaldson TA, Luthert PJ, Chong NV. Plasma levels of matrix metalloproteinase-2 and -9 (MMP-2 and MMP-9) in age-related macular degeneration. Eye 2008; 22: 855-859.

13 Amoaku WMK. The Royal College of Opthalmologists interim recommendations for the management of patients with age related macular degeneration. Eye 2008; 22: 864-868. 
14 Goverdhan SV, Hannan S, Newsom RB, Luff AJ, Griffiths H, Lotery AJ. An analysis of the CFH Y402H genotype in AMD patients and controls from the UK, and response to PDT treatment. Eye 2008; 22: 849-854.

15 Christen WG, Glynn RJ, Manson JE, Ajani UA, Buring JE. A prospective study of cigarette smoking and risk of age-related macular degeneration in men. JAMA 1996; 276: 1147-1151.

16 Cho E, Hung S, Willett WC, Spiegelman D, Rimm EB, Seddon JM et al. Prospective study of dietary fat and the risk of age-related macular degeneration. Am J Clin Nutr 2001; 73: 209-218.

17 AREDS. A randomized, placebo-controlled, clinical trial of high-dose supplementation with vitamins $\mathrm{C}$ and $\mathrm{E}$, beta carotene, and zinc for age-related macular degeneration and vision loss: AREDS report no. 8. Arch Ophthalmol 2001; 119: 1417-1436.

18 MPS Study Group. Subfoveal neovascular lesions in agerelated macular degeneration. Guidelines for evaluation and treatment in the macular photocoagulation study. Macular Photocoagulation Study Group [see comments]. Arch Ophthalmol 1991; 109: 1242-1257.

19 TAP Study Group. Verteporfin therapy for subfoveal choroidal neovascularization in age-related macular degeneration. Arch Ophthalmol 2002; 120: 1307-1314.

20 Bressler NM. Verteporfin therapy of subfoveal choroidal neovascularization in age-related macular degeneration: two-year results of a randomized clinical trial including lesions with occult with no classic choroidal neovascularization - verteporfin in photodynamic therapy report 2. Am J Ophthalmol 2002; 133: 168-169.

21 Rosenfeld PJ, Brown DM, Heier JS, Boyer DS, Kaiser PK, Chung CY et al. Ranibizumab for neovascular age-related macular degeneration. N Engl J Med 2006; 355: 1419-1431.
22 Gragoudas ES, Adamis AP, Cunningham Jr ET, Feinsod M, Guyer DR. Pegaptanib for neovascular age-related macular degeneration. N Engl J Med 2004; 351: 2805-2816.

23 Brown DM, Kaiser PK, Michels M, Soubrane G, Heier JS, Kim RY et al. Ranibizumab versus verteporfin for neovascular age-related macular degeneration. $N$ Engl J Med 2006; 355: 1432-1444.

24 Avery RL, Pieramici DJ, Rabena MD, Castellarin AA, Nasir MA, Giust MJ. Intravitreal bevacizumab (Avastin) for neovascular age-related macular degeneration. Ophthalmology 2006; 113: 363-372.

25 Cervantes-Castañeda RA, Banin E, Hemo I, Shpigel M, Averbukh E, Chowers I. Lack of benefit of early awareness to age-related macular degeneration. Eye 2008; 22: 777-781.

26 Leys A, Zlateva G, Shah SN, Patel M. Quality of life in patients with age-related macular degeneration: results from the VISION study. Eye 2008; 22: 792-798.

27 Rich RM, Rosenfeld PJ, Puliafito CA, Dubovy SR, Davis JL, Flynn Jr HW et al. Short-term safety and efficacy of intravitreal bevacizumab (Avastin) for neovascular age-related macular degeneration. Retina 2006; 26: 495-511.

28 Spaide RF, Laud K, Fine HF, Klancnik Jr JM, Meyerle CB, Yannuzzi LA et al. Intravitreal bevacizumab treatment of choroidal neovascularization secondary to age-related macular degeneration. Retina 2006; 26: 383-390.

29 Heussen FM, Fawzy NF, Joeres S, Lux A, Maaijwee K, Meurs JCV et al. Autologous translocation of the choroid and RPE in age-related macular degeneration: 1-year follow-up in 30 patients and recommendations for patient selection. Eye 2008; 22: 799-807. 